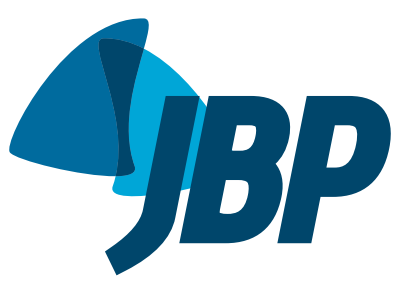

1. Instituto Nacional de Câncer José Alencar Gomes da Silva - INCA Rio de Janeiro (RJ) Brasil.

2. Instituto COI de Educação e Pesquisa Rio de Janeiro (RJ) Brasil.

3. Instituto do Câncer do Estado de São Paulo Octavio Frias de Oliveira - Icesp São Paulo (SP) Brasil.

4. Centro de Oncologia, Hospital SírioLibanês, São Paulo (SP) Brasil.

5. Instituto D'Or de Pesquisa e Ensino, Rio de Janeiro (RJ) Brasil.

6. Fundação do Câncer, Rio de Janeiro (RJ) Brasil.

7. Núcleo de Oncologia da Bahia, Salvador (BA) Brasil.

8. Centro Paulista de Oncologia São Paulo (SP) Brasil.

9. HCor Onco, São Paulo (SP) Brasil.

10. Hospital das Clínicas, Faculdade de Medicina, Universidade de São Paulo, São Paulo (SP) Brasil.

11. Faculdade Meridional IMED Passo Fundo (RS) Brasil.

12. Hospital de Câncer de Barretos, Barretos (SP) Brasil.

13. Centro Oncológico Antônio Ermírio de Moraes, São Paulo (SP) Brasil.

14. Instituto do Câncer do Ceará, Fortaleza (CE) Brasil.

15. A.C. Camargo Cancer Center, São Paulo (SP) Brasil.

16. Latin American Cooperative Oncology Group - LACOG - Porto Alegre (RS) Brasil.

17. Pontifícia Universidade Católica do Rio Grande do Sul, Porto Alegre (RS) Brasil.

a. (iD) $h t t p: / / o r c i d . o r g / 0000-0001-9486-7139$

b. (iD http://orcid.org/0000-0001-9539-3094

c. (iD) http://orcid.org/0000-0001-8765-3044

d. (iD http://orcid.org/0000-0002-1811-1169

e. iD http://orcid.org/0000-0002-7228-7018

f. iD http://orcid.org/0000-0002-6219-9858

g. (iD) http://orcid.org/0000-0001-6107-5098

h. iD http://orcid.org/0000-0002-1151-9903

i. iD http://orcid.org/0000-0003-0979-7768

j. (iD) http://orcid.org/0000-0003-2540-4506

k. (iD) http://orcid.org/0000-0001-8506-4414

I. ID http://orcid.org/0000-0001-9496-4596

m. iD http://orcid.org/0000-0002-6439-3136

n. (iD) http://orcid.org/0000-0001-5259-0215

o. iD http://orcid.org/0000-0001-8577-8708

p. (iD) http://orcid.org/0000-0003-3955-1101

q. (iD http://orcid.org/0000-0001-6271-105X

r. (iD) http://orcid.org/0000-0001-6021-667X

Submitted: 27 April 2017

Accepted: 10 July 2017

Study carried out by the Latin American Cooperative Oncology Group - LACOG - and the Grupo Brasileiro de Oncologia Torácica - GBOT - Porto Alegre (RS) Brasil.

\section{Lung cancer in Brazil}

Luiz Henrique Araujo ${ }^{1,2, a}$, Clarissa Baldotto, ${ }^{1,2, b}$, Gilberto de Castro Jr ${ }^{3,4, c}$, Artur Katz ${ }^{4, \mathrm{~d}}$, Carlos Gil Ferreira, ${ }^{5,6, \mathrm{e}}$, Clarissa Mathias ${ }^{7, f}$, Eldsamira Mascarenhas, 7, , Gilberto de Lima Lopes ${ }^{8,9, \mathrm{~h}}$, Heloisa Carvalho $4,10, \mathrm{i}$, Jaques Tabacof ${ }^{8}$, Jeovany Martínez-Mesa $a^{11, j}$, Luciano de Souza Viana ${ }^{12, k}$, Marcelo de Souza Cruz ${ }^{13, \mathrm{l}}$, Mauro Zukin ${ }^{1,2, \mathrm{~m}}$, Pedro De Marchi'12,n, Ricardo Mingarini Terra ${ }^{3,0}$, Ronaldo Albuquerque Ribeiro ${ }^{14}$, Vladmir Cláudio Cordeiro de Lima ${ }^{15, p}$, Gustavo Werutsky ${ }^{16, \mathrm{q}}$, Carlos Henrique Barrios ${ }^{17, r}$; Grupo Brasileiro de Oncologia Torácica

\section{ABSTRACT}

Lung cancer is one of the most incident types of cancer and a leading cause of cancer mortality in Brazil. We reviewed the current status of lung cancer by searching relevant data on prevention, diagnosis, and treatment in the country. This review highlights several issues that need to be addressed, including smoking control, patient lack of awareness, late diagnosis, and disparities in the access to cancer health care facilities in Brazil. We propose strategies to help overcome these limitations and challenge health care providers, as well as the society and governmental representatives, to work together and to take a step forward in fighting lung cancer.

Keywords: Lung neoplasms/epidemiology; Lung neoplasms/therapy; Lung neoplasms/ diagnosis; Biomarkers; Brazil.

\section{INTRODUCTION}

Lung cancer is the most common malignancy worldwide, accounting for $13 \%$ of all new cancer cases. ${ }^{(1)}$ According to the Global Burden of Disease Study 2015, lung cancer is also the leading cause of cancer mortality-over 1.7 to 1.8 million deaths every year and the highest age-standardized death rate (26.6 deaths per 100,000 population) among cancers. ${ }^{(2)}$ In Brazil, the Instituto Nacional de Câncer (INCA, Brazilian National Cancer Institute) estimated a total of 596,000 new cancer cases in $2016,28,220(4.7 \%)$ of which were primary lung malignancies. ${ }^{(3)}$ Lung cancer is $^{2}$ the second most incident cancer among men and the fourth most incident cancer among women in the country (Figure 1). ${ }^{(3)}$

As in most countries, lung cancer is the major cause of cancer mortality in Brazil. The age-standardized 5-year survival rate in the country is $18 \%$, which is concordant with global rates, ranging from $10 \%$ to $20 \%$. ${ }^{(4)}$ Lung cancer age-standardized mortality rates in 2012 were 16.5 deaths/100,000 population and 8.6 deaths/100,000 population in men and women, respectively. ${ }^{(5)}$ In Brazil, mortality increased from 10.6 deaths $/ 100,000$ population to 31.1 deaths/100,000 population in men and from 3.0 deaths $/ 100,000$ population to 5.4 deaths $/ 100,000$ population in women from 1979 to 2004. ${ }^{(6)}$ Mortality rates (both crude and age-adjusted) among men and women differed in magnitude in all periods (1980-2007), with a more significant relative increase among females than among males $(78.4 \%$ vs. $8.2 \%)$, which was probably related to differences in smoking prevalence (Figure 2). Moreover, agespecific mortality rates increased among men aged 65 years or older and among women across all age groups. ${ }^{(7)}$

The Brazilian health care system is divided into private and public coverage $(27 \%$ and $73 \%$, respectively). ${ }^{(8)}$ As will be discussed later in the present analysis, significant discrepancies in the availability of health care resources and patient outcomes are evident between these two different settings.

\section{RISK FACTORS AND TOBACCO EXPOSURE}

Trends in lung cancer mortality in Brazil reflect the epidemiological model of tobacco-related mortality. Tobacco use increased during the 1950 s and the 1960 s,

\section{Correspondence to:}

Luiz H. Araujo. Instituto Nacional de Câncer (INCA), Rua André Cavalcanti, 37, $5^{\circ}$ andar, prédio anexo, Centro, CEP 20231-050, Rio de Janeiro, RJ, Brasil.

Tel.: 5521 3207-6650. Fax: 5521 3207-6566. E-mail: luiz.lima@inca.gov.br

Financial support: None. 


\begin{tabular}{|c|c|c|c|c|c|c|}
\hline Prostate & 61,200 & $28.6 \%$ & & Breast & 57,960 & $28.1 \%$ \\
\hline Lung \& bronchus & 17,330 & $8.1 \%$ & MEN WOMEN & Colon \& rectum & 17,620 & $8.5 \%$ \\
\hline Colon \& rectum & 16,660 & $7.8 \%$ & & Uterine cervix & 16,340 & $7.9 \%$ \\
\hline Stomach & 12,920 & $6.0 \%$ & & Lung \& bronchus & 10,890 & $5.3 \%$ \\
\hline Oral cavity & 11,140 & $5.2 \%$ & & Stomach & 7,600 & $3.7 \%$ \\
\hline Esophagus & 7,950 & $3.7 \%$ & & Uterine corpus & 6,950 & $3.4 \%$ \\
\hline Urinary bladder & 7,200 & $3.4 \%$ & & Ovary & 6,150 & $3.0 \%$ \\
\hline Larynx & 6,360 & $3.0 \%$ & & Thyroid & 5,870 & $2.9 \%$ \\
\hline Leukemias & 5,540 & $2.6 \%$ & & Non-Hodgkin lymphoma & 5,030 & $2.4 \%$ \\
\hline Central nervous system & 5,440 & $2.5 \%$ & & Central nervous system & 4,830 & $2.3 \%$ \\
\hline
\end{tabular}

Figure 1. Brazilian National Cancer Institute estimate for new cancer cases in 2016 by gender. Adapted from Instituto Nacional de Câncer José Alencar Gomes da Silva. ${ }^{(3)}$

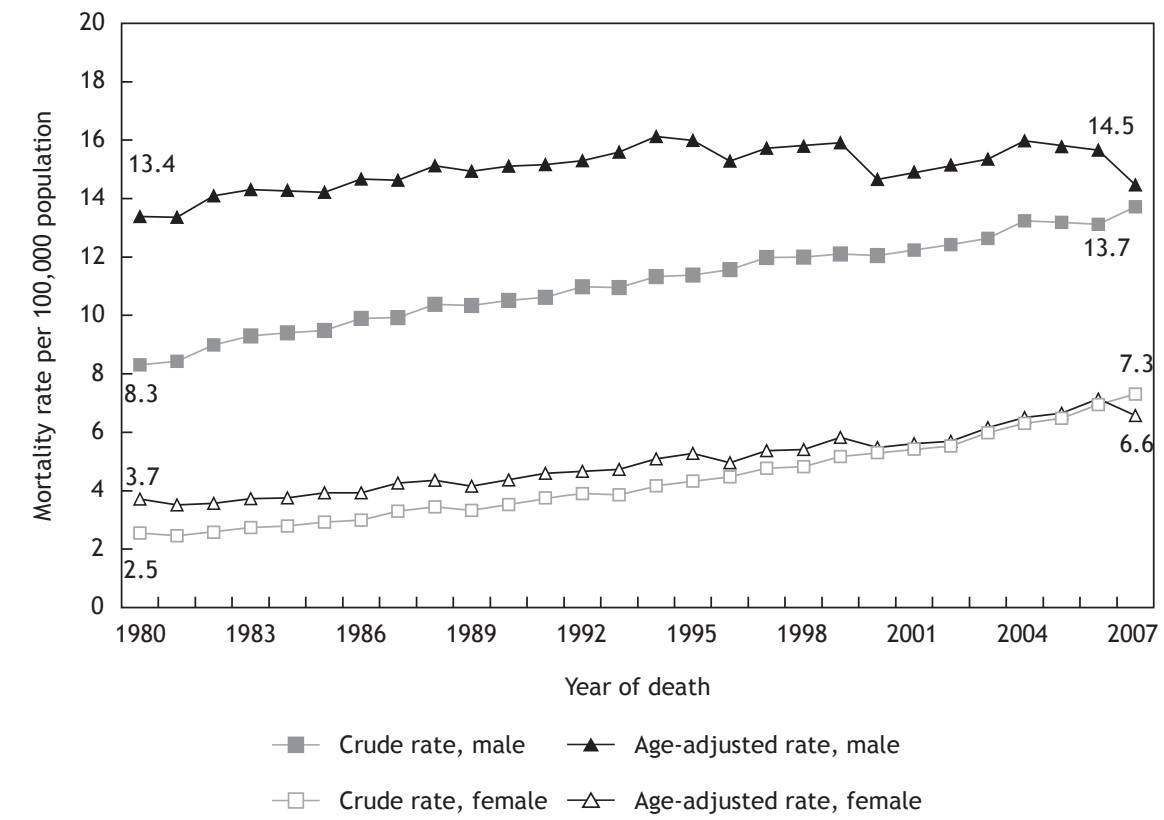

Figure 2. Crude and age-adjusted lung cancer mortality rates by gender. Brazil, 1980-2007.(7)

peaking in the 1970s. Notably, strong public health policies in Brazil have led to a subsequent reduction in tobacco consumption, which may serve as an example for other low- and middle-income countries. Brazilian national studies indicate that smoking prevalence has diminished approximately $50 \%$, as have tobacco-related deaths. ${ }^{(9)}$ Data from a nationwide surveillance study of risk factors and protective factors for chronic diseases carried out by telephone inquiries showed that $12,7 \%$ of men and $8.0 \%$ of women aged 18 years or older were smokers in $2016^{(10)}$; those proportions were $43.3 \%$ and $27.0 \%$ in 1989 , respectively. ${ }^{(11)}$

The major components of Brazilian anti-tobacco policies include prohibition of smoking in public places, higher taxes for tobacco products, and health-warning labels on cigarette packages. Despite this decline in tobacco consumption, national surveys involving children in Brazil still show a significant prevalence of smokers among the young population in various cities. $^{(12)}$ Moreover, smoking-related illnesses remain a major economic health burden. It has been estimated that, by 2020 , the population-attributable fraction of the lung cancer burden associated with smoking in Brazil will be $83.3 \%$ among men and $64.8 \%$ among women. ${ }^{(13)}$ These data are relevant to reinforce the role of local tobacco control. Data on the prevalence of lung cancer related to other risk factors, such as asbestos exposure, residential wood smoke exposure, and radon exposure, are lacking.

\section{DIAGNOSIS AND STAGING}

Data on how lung cancer is diagnosed and staged are relatively scarce in Brazil; however, some datasets have been published in the past 15 years. Similarly to what occurs in developed countries, non-small cell lung cancer (NSCLC) is usually diagnosed in advanced stages and has poor survival rates in Brazil. Overall, approximately $70 \%$ of the patients present with either 
locally advanced or metastatic disease (stages III and IV, respectively). According to a large cancer registry database in the state of São Paulo, Brazil, only $8.8 \%$ of the 20,850 lung cancer patients registered in the system between 2000 and 2010 had stage I disease. ${ }^{(14)}$ These proportions are in contrast with the higher frequencies of $15.4 \%$ and $14.5 \%$ reported for a similar period in the USA and in the United Kingdom, respectively. ${ }^{(15,16)}$ A Brazilian lung cancer screening trial was conducted in order to address the effectiveness of screening in the country. ${ }^{(17)}$ Between January of 2013 and July of 2014, 790 participants volunteered to participate, following the same eligibility criteria applied in a USA national lung screening trial. NSCLC was diagnosed in 10 participants (prevalence of $1.3 \%$ ), most of whom were classified as stage I. ${ }^{(17)}$

Several retrospective series have been published reporting single institution data on lung cancer histology, staging, and outcomes (Table 1).(18-26) Interestingly, it seems that squamous cell histology is more prevalent in public health care services, whereas adenocarcinoma predominates in private institutions. In the USA, squamous cell carcinoma and small cell lung carcinoma (SCLC) rates declined after the 1990s, and adenocarcinoma rates rose in the period between 2006 and 2010 among every racial/ethnic/ sex group. (27) A major cancer center in the state of São Paulo reviewed data collected between 1997 and 2008 from 1,887 lung cancer patients. ${ }^{(18)}$ A decline in the proportion of SCLC was reported in two different time periods (1997-2002 and 2003-2008), although no significant changes occurred in the NSCLC histological subgroups. ${ }^{(18)}$ However, in an epidemiological study evaluating case registry data from 35,018 patients diagnosed with NSCLC in the states of Rio de Janeiro and São Paulo between 2000 and 2011, a shift was observed towards a prevalence of adenocarcinoma histology over squamous cell carcinoma (43.3\% vs. $36.5 \%)$ in recent years. ${ }^{(28)}$

\section{DIAGNOSTIC PROCEDURES}

Delay in the diagnosis of cancer in general and of lung cancer in particular is one of the major challenges faced in Brazil. Information on the timeframe for an individual with suspicious symptoms to receive a diagnosis of lung cancer, to visit a tertiary health care facility, and to initiate therapy is lacking. Nonetheless, the high rate of late-stage diagnoses, the low frequency of patients receiving curative-intent therapy, and the large number of patients not receiving any disease-directed treatment reflect a significant delay and inefficiency in the diagnostic workflow, at least in the public health care scenario. ${ }^{(21,29)}$ In general, access to diagnostic imaging is limited in many regions. A retrospective study from two institutions showed that $89 \%$ of the patients were diagnosed with cancer via chest X-ray, whereas only $20 \%$ were diagnosed via CT. ${ }^{(21)}$ Moreover, access to invasive diagnostic procedures is limited, with few facilities performing bronchoscopy or transthoracic biopsies.

In a 2005 survey, the rate of CT scanners per one million population was 4.9 and 30.8 in the public and private health care settings in Brazil, respectively. ${ }^{(30)}$ These rates underscore the difficulties in the access to adequate diagnostic evaluation in the public health care system, whereas the rates described in private health care facilities are similar to those in developed countries, such as the USA and Japan (31.5 and 32.2, respectively). There is also a geographic disproportion of technology distribution, with higher numbers of diagnostic facilities in the southeast and south regions and lower numbers in the north and northeast regions. ${ }^{(30)}$ In 2010, the agency that regulates the private medical sector-Agência Nacional de Saúde Suplementar (National Health Insurance Agency)-approved the use of positron emission tomography (PET) for lung cancer staging; however, the public health care system-Sistema Único de Saúde (Brazilian Unified Health Care System)-incorporated the technology only in 2014. The number of facilities providing PET has increased sharply in the country, reaching 124 scanners and 15 cyclotrons in 2014, distributed in 21 of the 26 states of Brazil and the Federal District of Brasília (personal communication). The lower availability of the technology in the public health care system is noteworthy.

Reports on the Brazilian experience with invasive diagnostic procedures are also scarce or outdated. The Sociedade Brasileira de Pneumologia e Tisiologia mailed 576 questionnaires to physicians-mostly pulmonologists-addressing their experience

Table 1. Lung cancer distribution by histology and staging.

\begin{tabular}{|c|c|c|c|c|c|}
\hline Author & $\mathbf{N}$ & Type of facility & NSCLC, $\%$ & SCC/Ad ratio & III-IV, \% \\
\hline Ismael et al. ${ }^{(18)}$ & 1,887 & Public & 89 & 0.93 & 71 \\
\hline Younes et al. ${ }^{(19)}$ & 737 & Public & $100^{\mathrm{a}}$ & 1.20 & 74 \\
\hline Westphal et al. ${ }^{(20)}$ & 352 & Public & 91 & 2.54 & 66 \\
\hline Barros et al. ${ }^{(21)}$ & 263 & Public & 87 & 1.96 & 94 \\
\hline Novaes et al.(22) & 240 & Public & 80 & 1.25 & 72 \\
\hline Araujo et al. ${ }^{(23)}$ & 566 & Private & $100^{\mathrm{a}}$ & 0.33 & 80 \\
\hline Caires-Lima et al.(26) & 232 & Public & 92 & 0.48 & 93 \\
\hline Mascarenhas et al.(24) & 338 & Private & 83 & 0.38 & 78 \\
\hline Freitas et al. (25) & 93 & Private & $100^{\mathrm{a}}$ & 0.33 & 88 \\
\hline
\end{tabular}

NSCLC: non-small cell lung cancer cases; SCC: squamous cell carcinoma cases; Ad: adenocarcinoma cases; and III-IV: patients in stages III or IV. aStudies including only NSCLC cases. 
with bronchoscopy. ${ }^{(31)}$ Of the respondents, 111 $(19.2 \%)$ declared being familiar with both flexible and rigid bronchoscopy, the majority of those ( $n$ $=63 ; 56.7 \%$ ) performing at least 100 fiberoptic bronchoscopies per year, which is in line with international recommendations. ${ }^{(32,33)}$ In 2007, experts at INCA reported their experience with bronchoscopyguided transbronchial needle aspiration, which is considered a safe and effective procedure. ${ }^{\left({ }^{34}\right)}$ Samples were deemed satisfactory in $57 \%$ of the cases, $81 \%$ of those allowing a definitive diagnosis. ${ }^{(34)}$ Some groups have also developed expertise in CT-guided transthoracic fine-needle aspiration, showing high diagnostic yield, accuracy, and safety. ${ }^{(35)}$ After 2010, endobronchial ultrasound was introduced in a few large institutions, and the initial experience with 50 cases has been reported. ${ }^{(36,37)}$ In most cases, endobronchial ultrasound was recommended for diagnostic purposes (76\%), yielding adequate specimens in $74 \%$ of the cases. ${ }^{(36)}$ In general, these data suggest that referral centers have adequate expertise, but it is unknown what proportion of patients has access to these.

\section{MOLECULAR TESTING}

The introduction of molecular testing in lung cancer is key to improving therapeutic results. Unfortunately, access, affordability, and incorporation strategies remain significant challenges in low- and middle-income countries. ${ }^{(38)}$ Access to molecular testing is limited in Brazil, and data on the frequency of clinically useful mutations is still scarce, especially in the public health care system. Unpublished information (personal communication) on approximately 1,700 cases obtained from a marketing survey conducted in the first half of 2014, suggests that, overall, fewer than half of the patients are tested for EGFR mutations in Brazil. Approximately two thirds of the tests are performed in the private sector, and only one third is performed in public health care institutions. These rates are likely to be lower for anaplastic lymphoma kinase ( $A L K)$ gene testing. (39) The major issues regarding molecular genotyping are as follows: 1 ) reimbursement and logistics; 2) access to targeted therapy; 3) patient and medical information (i.e., unawareness); and 4) limited laboratory infrastructure for molecular testing (restricted to a few large centers or cities). Pharmaceutical companies involved in distributing EGFR tyrosine kinase inhibitors (TKIs) have provided most of the molecular testing that has been performed in the past few years. Regulatory agencies have recently approved EGFR testing and the reimbursement of its costs by private health insurance companies. The development of local guidelines, the definition of test algorithms, and the application of comprehensive policies that associate testing with personalized treatment are essential to enable a functional process to make targeted therapy a reality for a larger proportion of patients. ${ }^{(39)}$

Some efforts have been made to compile data on the frequency of molecular abnormalities in Brazilian patients (Table 2). ${ }^{(40-48)}$ Overall, the data suggest that the frequency of EGFR mutations is lower in Brazil (approximately 25\%) than in Asia but higher than in White populations in North America and Europe (Figure 3), confirming findings from other Latin American countries. ${ }^{(49)}$ It has been speculated that the ethnic background could be responsible for the distinct molecular profile seen in these instances, perhaps due to the characteristic genetic admixture seen in Brazilians, inherited from European, African, and Native American ancestors. The frequency of $A L K$ translocations has been reported to range from $3 \%$ to $4 \%{ }^{(48,50,51)}$ To explore these points in a better way, two multicenter studies have been initiated, led by the Brazilian National Clinical Cancer Research Network and the Latin American Cooperative Oncology Group. These consortiums are supported by pharmaceutical companies, as well as by North American societies, such as the American Society of Clinical Oncology and the American Association for Cancer Research.

\section{TREATMENT}

\section{Surgery}

Precise data on the number of surgical procedures performed to treat lung cancer are unavailable. According to the Brazilian Technology Information Department of the SUS-a public health care system database that covers approximately $75 \%$ of the Brazilian population-a median of 964 pulmonary lobectomies and segmentectomies were performed yearly between 2007 and 2014. (52) However, this number has some potential flaws, though, since lobectomies and segmentectomies could have been performed for diseases other than lung cancer; the database is restricted to the public health care system, and the quality of the data is questionable.

Only a limited proportion of patients undergo curativeintent surgery. Data suggest that approximately $25 \%$ of the patients undergo surgical treatment. $(19,22,23)$ Access to curative surgery is likely influenced by socioeconomic differences, performance status scores, presence of comorbidities, advanced age, and geographic distribution. ${ }^{(22)}$ According to the São Paulo State Department of Health, patients with a lower educational level are less likely to undergo surgery. ${ }^{(14)}$ Currently, there are 763 thoracic surgeons in Brazil, concentrated in the south and southeast regions of the country. ${ }^{(53)}$ In a survey promoted by the Sociedade Brasileira de Cirurgia Torácica (Brazilian Society of Thoracic Surgery), $51 \%$ of the respondents stated that they worked in cities with more than one million inhabitants. ${ }^{(54)}$ Therefore, although the absolute number of thoracic surgeons is adequate, their distribution is a cause for concern. Medium-sized cities and highly populated regions in central, northern, and northeastern Brazil are underserved in terms of thoracic surgery.

Video-assisted thoracic surgery is rapidly growing in the country. The 30-day mortality rates in the two largest surgical case series reported, which included 
Table 2. Frequency of EGFR mutations and clinical characteristics in Brazilian cohorts.

\begin{tabular}{|c|c|c|c|c|c|c|}
\hline Author & $\mathbf{N}$ & EGFR mutation, \% & NS, \% & Female, \% & non-SCC, \% & Setting \\
\hline Pontes et al. ${ }^{(40)}$ & 3,371 & 25 & NR & 58 & 100 & Clinical \\
\hline Yen et al. ${ }^{(45)}$ & 417 & 25 & 34 & 57 & 100 & Clinical \\
\hline Saito et al. ${ }^{(46)}$ & 395 & 26 & 27 & 51 & 91 & Clinical \\
\hline Domingues et al. ${ }^{(43)}$ & 288 & 27 & 26 & 56 & 95 & Clinical \\
\hline Bacchi et al. ${ }^{(41)}$ & 207 & 30 & 54 & 58 & 82 & Clinical \\
\hline Gomes et al. ${ }^{(48)}$ & 162 & 33 & 32 & 48 & 100 & Clinical \\
\hline Melo et al. ${ }^{(42)}$ & 157 & 22 & 15 & 47 & 68 & Research \\
\hline De Sa et al. ${ }^{(44)}$ & 100 & 28 & NR & NR & 100 & Clinical \\
\hline
\end{tabular}

NS: never smoker; non-SCC: non-squamous cell carcinoma; and NR: not reported.

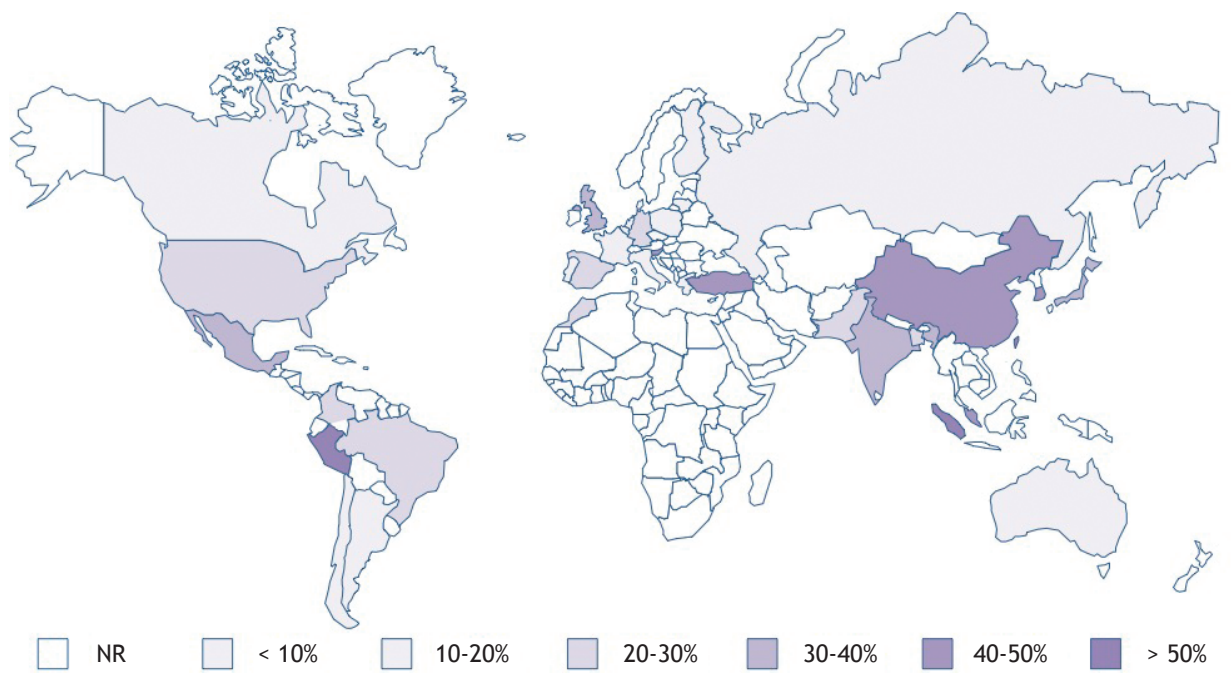

Figure 3. Prevalence of EGFR mutations around the world. EGFR mutations are in general more prevalent in Asian countries, whereas Latin American countries tend to have an intermediate prevalence between Asia and Europe/NorthAmerica. NR: not reported. Adapted from Werustky et al. ${ }^{(49)}$

patients who underwent lobectomy due to lung cancer were $2.9 \%$ and $4.3 \% .^{(55,56)}$ Large international case series published in the 2000s showed a somewhat lower mortality rate (of approximately $1 \%$ ). ${ }^{(57)}$ These numbers suggest that there is room for improvement in lung cancer surgery in Brazil. The dissemination and availability of new techniques, such as video-assisted and robotic surgery, will hopefully speed up this process.

\section{Radiation therapy}

According to the Comissão Nacional de Energia Nuclear (Brazilian National Commission of Nuclear Energy), there 224 radiation therapy (RT) facilities (65\% of which are public) are currently available in Brazil, but they are unequally distributed across the country ( 2 of the 26 states lack RT facilities). ${ }^{(58)}$ These facilities have approximately 250 linear accelerators that can provide treatment for more than 150,000 cancer patients per year. The World Health Organization recommends one megavoltage machine for every 600,000 inhabitants in order to provide adequate treatment availability. With an estimated population of 200 million inhabitants, Brazil needs approximately 335 megavoltage machines. This corresponds to a deficiency of nearly 100 RT devices to provide full treatment coverage for approximately 100,000 untreated patients per year. ${ }^{(59)}$

Approximately 550 radiation oncologists work in Brazil, mostly in the southeastern region, where the majority of the linear accelerators (124/235 units; $52.7 \%)$ are centralized. (60) There are long waiting lists to start treatment (mean waiting time, 113 days) mainly in public health care centers, with a potential impact on patient outcome. In order to minimize this problem, the government has implemented different strategies. ${ }^{(60)}$ The most recent and outstanding one was the acquisition of 80 linear accelerators that are able to deliver high-quality therapy, including threedimensional conformal RT and potential for upgrades to deliver intensity-modulated RT. At the same time, 39 of the already existing RT facilities are intended to be expanded, and 41 RT facilities are to be created, the federal government investing more than 250 million US dollars. As a result, it is expected that all geographic areas in the country should be properly served in the near future, avoiding patient migration for treatment. Nevertheless, the backlog of patients requiring therapy and the need to train qualified human resources remain as critical challenges in need of urgent measures. 
According to a survey sent to all RT services registered with the Sociedade Brasileira de Radioterapia (Brazilian Society of Radiotherapy), approximately $25 \%$ of all RT procedures are performed in lung cancer patients. Among these, approximately half are submitted to palliative treatment only, and very few are in early stages (I or II). Few centers have stereotactic body RT or stereotactic ablative RT to treat localized disease, only one of them providing care via the public health care system. Among the 13 centers that provide this technology, only 10 use it for lung cancer treatment. The preliminary experience (21 patients; mean age, 81 years) with stereotactic body RT in a private health care institution showed that the treatment was mostly recommended for elderly or clinically inoperable patients. With a median follow-up period of 12 months, local control was achieved in $95 \%$ of the patients, and the complication rate was very low. ${ }^{(61)}$

There is a lack of well-annotated outcome data on locally advanced NSCLC in Brazil. Although chemoradiation therapy is the standard of care in most facilities, treatment protocols are quite diverse. For instance, in a retrospective analysis of 171 elderly patients with unresectable, locally advanced NSCLC, the treatment offered was best supportive care, in $39 \%$; definitive RT alone (at least $40 \mathrm{~Gy}$ ), in 32\%; and combined chemoradiation therapy, in only $29 \%$. ${ }^{(62)}$ In order to improve the description of the results regarding this issue in Brazil, the Latin American Cooperative Oncology Group and the Grupo Brasileiro de Oncologia Torácica are coordinating a multicenter study to collect data on locally advanced NSCLC from 7 referral centers for cancer in the country.

The Brazilian experience with palliative RT demonstrates high rates of symptom control (70-84\%) and a median overall survival (OS) of approximately 3 months following hypofractionated regimens. ${ }^{63,64)}$ Regimens based on fewer RT fractions can be very convenient in centers with long waiting lines. High doserate brachytherapy is also available in approximately half of the centers, although reimbursement in public health care services is limited to gynecological cancers. ${ }^{(65)}$ The endobronchial procedure is used mostly for palliative purposes and in very few centers (11/59 surveyed), only 1 belonging to the public health care system. The overall symptom relief rate was $70 \%$ in a national case series involving 78 patients. ${ }^{(66)}$

\section{Systemic therapy}

In comparison with developed countries, the incorporation of systemic therapies and technologies for lung cancer diagnosis and treatment suffers from significant delays in Brazil. More importantly, inequities in the access to drugs and molecular testing between public and private health care systems are striking. For instance, standard third-generation chemotherapy agents, such as taxanes and gemcitabine, were only incorporated into the public health care system in the late 2000s, and pemetrexed is still unavailable. Targeted therapies, such as monoclonal antibodies (bevacizumab) and first-generation EGFR TKIs, are available only for patients with private health care coverage. Although EGFR TKIs were included in the public health care system in 2015 , both mutation testing and medications are neither adequately available nor routinely provided to patients yet. The first ALK inhibitor approved for use in Brazil was crizotinib in February of 2016, whereas ceritinib is still being evaluated. The delay in the approval of crizotinib was estimated to result in over 700 patients dying prematurely from their disease as a consequence of the lack of access to this effective agent. ${ }^{(67)}$

In a large retrospective review, Younes et al. collected data from 2,673 metastatic NSCLC patients treated in two cancer centers in the city of São Paulo between 1990 and 2008. ${ }^{(68)}$ Notably, 49\% of the patients had a Karnofsky performance status of $70 \%$ or less, reflecting the late access of the patients to specialized cancer centers. The majority (57.9\%) of the patients were treated with first-line chemotherapy, whereas secondand third-line chemotherapy was offered to $23.4 \%$ and $8.0 \%$ of the patients, respectively. A platinum-based regimen as the first-line treatment was used in $61 \%$ of the patients (median OS, 8.0 months). ${ }^{(68)}$ Naime et al. reviewed the heterogeneity of systemic regimens employed in a cohort of 564 metastatic NSCLC patients, also in the city of São Paulo, between 1990 and 2003. ${ }^{(69)}$ Again, $47 \%$ of the patients had an Eastern Cooperative Oncology Group performance status scale score of 2-3; chemotherapy was used in $59 \%$ of the patients, 47 different regimens being used. Although most $(83.5 \%)$ of the patients received a platinum salt, only $57.3 \%$ were treated with a platinum doublet regimen. Taxanes and gemcitabine were offered to only $19.0 \%$ and $15.8 \%$ of patients, respectively. The median OS was 8.3 months. ${ }^{(69)}$ Araujo et al. reported the results of palliative chemotherapy given to 339 NSCLC patients treated in a private health care institution in the city of Rio de Janeiro between 1998 and 2010.(23) Most patients received a first-line platinum-based regimen, its combination with paclitaxel being the most common, in $31 \%$; followed by pemetrexed, in $21 \%$; and gemcitabine, in $17 \%$. The median OS was 12.2 months. ${ }^{(23)}$ These and other studies are summarized in Table 3.

Given the relatively high rate of patients being diagnosed late and having advanced disease and poor performance status, Brazilian investigators established a national research infrastructure to explore the best approach to manage fragile patients. In a multi-institutional phase III trial, Zukin et al. compared a carboplatin plus pemetrexed regimen with the use of pemetrexed alone in 205 metastatic NSCLC patients with a performance status of 2. ${ }^{(70)}$ Notably, the authors confirmed the benefit of the platinumdoublet regimen, showing improved overall response rate, progression-free survival, and OS in the group receiving the combined therapy. In parallel, Pereira et al. demonstrated the feasibility of a cisplatin plus vinorelbine regimen for elderly patients with NSCLC in a prospective phase II trial. ${ }^{(71)}$ 
Several groups have reported their experience with targeted therapies in Brazil, especially regarding their local experience with EGFR TKIs. Caires-Lima et al. reported the efficacy and safety of erlotinib in patients with advanced adenocarcinoma harboring sensitizing EGFR mutation. ${ }^{(72)}$ In that single-center experience in the city of São Paulo, 49 consecutive cases treated between 2010 and 2013 were evaluated; of those, $22 \%$ were treated with a first-line regimen, and $63 \%$ and $14 \%$ were treated with second-line and third-line regimens, respectively. Treatment was well tolerated and led to a clinical benefit rate of $64 \%$. One-year OS rate was $94 \%$, and the median survival had not been reached at the time of publication. ${ }^{(72)}$ Domingues et al. described the outcomes of 32 EGFR mutant cases treated with EGFR TKIs in the city of Rio de Janeiro. ${ }^{(43)}$ The median OS was an impressive 62.9 months. ${ }^{(43)}$ Freitas et al. reported the outcomes of 61 patients treated with a TKI (from a cohort of 115 metastatic NSCLC patients with an EGFR mutation) in another cancer institution in the city of São Paulo between 2010 and 2014. ${ }^{(73)}$ The median progression-free survival was 13.9 months and 11.4 months in the patients using first-line and the second-line regimens, respectively. The median OS was not different between those two groups (36.3 months vs. not reached; $p=0.61$ ). ${ }^{(73)}$ These data confirm the benefit of selecting patients locally and reinforce the importance of correct identification of EGFR mutant cases for targeted therapy.

Given that these medications have only recently been approved, there is still no information regarding the use of immunotherapy in the country.

\section{CLINICAL RESEARCH AS AN OPPORTUNITY}

The participation of patients in international, industry-sponsored clinical trials has been significant in various academic institutions in Brazil and has facilitated access to novel therapies. For instance, Zylberberg et al. reported the experience involving 97 consecutive patients with advanced NSCLC enrolled in clinical trials at INCA. ${ }^{(74)}$ Half of the patients were initially enrolled in a first-line regimen trial; of those patients, $31 \%$ also participated in a subsequent trial using a second-line regimen or a later-line regimen. Notably, all patients eventually received a contemporary standard treatment, as follows: taxanes, in $49 \%$ of the patients; pemetrexed, in 30\%; gemcitabine, in $31 \%$; and TKIs, in $37 \%$. This highly selected group had a median OS of 17.2 months, which is higher than are the historical data outside of a clinical trial. ${ }^{(74)}$ As more trials are open nationally, the participation of community-based institutions tends to increase, making research an option for more patients. Clinical research in Brazil faces a number of challenges, including the slow and lengthy regulatory process that reduces and significantly limits the opportunities to participate in clinical trials. The mean time for regulatory approval of a research protocol in Brazil is three times longer than that in the USA and other leading countries in research, having an impact on the availability of studies and reducing the timeframe for patient accrual.

\section{PERSPECTIVES}

Investing in epidemiological research and evidencebased lung cancer care should be a strategic priority for the Brazilian health care system. Important steps have been undertaken to improve case registry data; however, those available still cover only a small proportion of the population, and the quality of data collection is often questionable. Lung cancer control certainly faces significant challenges in Brazil (Chart 1). Collecting highquality data on epidemiology and health economy will help understand the current scenario and will contribute

Table 3. Summary of the most relevant studies on non-small cell lung cancer palliative systemic treatment in Brazil.

\begin{tabular}{|c|c|c|c|c|c|c|}
\hline Author & Design & $\mathbf{N}$ & Study period & PS $\geq 2, \%$ & Type of facility & mOS, months \\
\hline \multicolumn{7}{|l|}{ Chemotherapy } \\
\hline Younes et al. ${ }^{(68)}$ & $\operatorname{Re}$ & 2,673 & $1990-2008$ & $49^{a}$ & Private & 8.0 \\
\hline Naime et al. ${ }^{(69)}$ & $\operatorname{Re}$ & 564 & $1990-2003$ & 47 & Private & 8.3 \\
\hline Araujo et al. ${ }^{(23)}$ & $\operatorname{Re}$ & 339 & $1998-2010$ & 11 & Private & 12.2 \\
\hline Leite et al. ${ }^{(75)}$ & $\operatorname{Re}$ & 163 & $2006-2013$ & NA & Public & NA \\
\hline Zukin et al. ${ }^{(70)}$ & Pro & 205 & $2008-2011$ & 100 & Public & $5.3 / 9.3^{b}$ \\
\hline Pereira et al. ${ }^{(76)}$ & $\operatorname{Re}$ & 82 & $2007-2011$ & NA & Private & $26.4 / 16.4^{c}$ \\
\hline Jardim et al. ${ }^{(77)}$ & $\operatorname{Re}$ & 56 & $2006-2011$ & 7.2 & Private & 14.8 \\
\hline Pereira et al. ${ }^{(71)}$ & Pro & 44 & 1996-1998 & $50^{\mathrm{a}}$ & Public & $7.5^{\mathrm{d}}$ \\
\hline \multicolumn{7}{|l|}{ EGFR TKI } \\
\hline Caires-Lima et al. ${ }^{(72)}$ & $\operatorname{Re}$ & 49 & $2010-2013$ & NA & Public & $\mathrm{NR}^{\mathrm{e}}$ \\
\hline Domingues et al. ${ }^{(43)}$ & $\operatorname{Re}$ & 32 & $2011-2014$ & NA & Public & 62.9 \\
\hline Freitas et al. ${ }^{(73)}$ & $\operatorname{Re}$ & 61 & $2010-2014$ & NA & Private & $36.3 / \mathrm{NR}^{\mathrm{f}}$ \\
\hline
\end{tabular}

PS: Eastern Cooperative Oncology Group performance status score; mOS: median overall survival; Re: retrospective; Pro: prospective; NA: not available; NR: not reached; and TKI: tyrosine kinase inhibitor. akarnofsky performance status $\leq 70 \%$. 'burvival for single-agent and doublet-agent arms, respectively. 'Survival for bevacizumab-based and

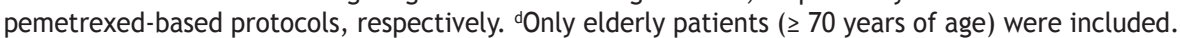

eSurvival not reached after a median follow-up of 14 months. 'Survival among patients receiving an EGFR TKI as firstor second-line treatment, respectively. 
Chart 1. Summary of the current scenario and proposed actions to improve lung cancer control in Brazil.

\begin{tabular}{|c|c|}
\hline Current scenario & Action \\
\hline $\begin{array}{l}\text { Lung cancer is a leading cause of cancer death in Brazil. } \\
\text { Smoking-related lung cancer remains a major health } \\
\text { burden. } \\
\text { Data on lung cancer diagnosis, staging, therapy, and } \\
\text { outcomes are scarce. } \\
\text { There is a deficiency in radiation therapy machines to } \\
\text { provide full treatment coverage in the country. } \\
\text { There is a significant delay in the approval of systemic } \\
\text { therapies by local regulatory agencies. } \\
\text { Inequities in the access to diagnosis, therapy, and } \\
\text { molecular testing between public and private health care } \\
\text { systems are remarkable. } \\
\text { A lengthy clinical research approval process limits access } \\
\text { to clinical trial opportunities. }\end{array}$ & $\begin{array}{l}\text { Reinforce the role of tobacco control, and stimulate } \\
\text { programs directed to the entire population, particularly } \\
\text { teenagers. } \\
\text { Collect high-quality data on epidemiology and health } \\
\text { economy aiming at describing diagnosis, staging, access } \\
\text { to therapy, and outcomes. } \\
\text { Strengthen, bring together, and stimulate productive } \\
\text { dialogue among medical societies, advocacy groups, } \\
\text { government, pharmaceutical companies, and regulatory } \\
\text { agencies. } \\
\text { Propose and implement programs to positively impact on } \\
\text { prevention, diagnosis, and access to therapy. } \\
\text { Increase local funding for lung cancer prevention, } \\
\text { diagnosis, and treatment research. } \\
\text { Stimulate the development of research units and } \\
\text { participation in clinical trials. } \\
\text { Stimulate and implement international collaborations. }\end{array}$ \\
\hline
\end{tabular}

to the process of defining strategic plans. Promising examples include local studies showing favorable cost-effectiveness ratios that support the incorporation of PET-CT for lung cancer staging in the public health care system, as well as chemotherapy doublets in the first-line treatment of metastatic NSCLC patients with a performance status of 2 . Bringing together community representatives, health care providers, pharmaceutical companies, tax payers, researchers, and government officials is an important strategy to enable the definition and implementation of programs that will have impact on the areas of prevention, diagnosis, and access to standard therapies. The participation of oncology societies and workgroups will be key to orchestrating such efforts. These strategies should involve international collaboration and strongly focus on decreasing health care discrepancies.

\section{FINAL CONSIDERATIONS}

This comprehensive review addresses the current landscape and emphasizes various weaknesses in the management of lung cancer in Brazil. Specific data are often scarce or absent in various instances, which should motivate concentrated efforts to address these topics in the near future. Anti-tobacco legislation and education campaigns should be continued and intensified, particularly focusing on the younger population. Programs to increase public awareness on lung cancer, stimulate smoking cessation, shorten the time to diagnosis, and improve access to specialized health care facilities are among the most relevant needs to tackle lung cancer and improve therapeutic results.

\section{ACKNOWLEDGEMENTS}

The authors would like to thank the Brazilian Thoracic Association, José Leite Filho, Edson Roman, and Close-up International for providing valuable information and guidance on the available data on diagnostic procedures. This study is dedicated to Ronaldo A. Ribeiro (in memoriam) for his invaluable contribution in patient care, research, and teaching in Brazil.

\section{REFERENCES}

1. World Health Organization. International Agency for Research on Cancer (IARC) [homepage on the Internet]. Lyon: IARC; c2016 [cited 2016 Mar 1]. GLOBOCAN 2012: Estimated Cancer Incidence, Mortality and Prevalence Worldwide; 2013. Available from: http:/ globocan.iarc.fr

2. GBD 2015 Mortality and Causes of Death Collaborators. Global regional, and national life expectancy, all-cause mortality, and cause-specific mortality for 249 causes of death, 1980-2015: a systematic analysis for the Global Burden of Disease Study 2015 Lancet. 2016;388(10053):1459-1544. https://doi.org/10.1016/S01406736(16)31012-1

3. Brasil. Ministério da Saúde. Instituto Nacional de Câncer José Alencar Gomes da Silva (INCA) [homepage on the Internet]. Rio de Janeiro: INCA; [cited 2016 Jan 2]. Estimativa 2016: Incidência de Câncer no Brasil; 2015. Available from: http/inca.gov.br

4. Allemani C, Weir HK, Carreira H, Harewood R, Spika D, Wang XS, et al. Global surveillance of cancer survival 1995-2009: analysis of individual data for $25,676,887$ patients from 279 population-based registries in 67 countries (CONCORD-2). Lancet. 2015;385(9972):9771010. https://doi.org/10.1016/S0140-6736(14)62038-9

5. Brasil. Ministério da Saúde. Instituto Nacional de Câncer José Alencar Gomes da Silva (INCA) [homepage on the Internet]. Rio de Janeiro:
INCA; [cited 2015 Oct 1]. Estatísticas do Câncer: Mortalidade. Available from: http://inca.gov.br/vigilancia/mortalidade.asp

6. Boing AF, Rossi TF. Temporal trend in and spatial distribution of lung cancer mortality in Brazil between 1979 and 2004 magnitude, regional patterns, and gender-related differences. J Bras Pneumol. 2007;33(5):544-51. https://doi.org/10.1590/S180637132007000500009

7. Souza MC, Vasconcelos AG, Cruz OG. Trends in lung cancer mortality in Brazil from the 1980s into the early 21st century: ageperiod-cohort analysis. Cad Saude Publica. 2012;28(1):21-30. https:// doi.org/10.1590/S0102-311X2012000100003

8. Ministério do Planejamento, Orçamento e Gestão. Instituto Brasileiro de Geografia e Estatística (IBGE) [homepage on the Internet]. Rio de Janeiro: IBGE [cited 2016 Mar 2]. Pesquisa Nacional por Amostra de Domicílios 2008. Available from: http://www.ibge.gov.br

9. Levy D, de Almeida LM, Szklo A. The Brazil SimSmoke policy simulation model: the effect of strong tobacco control policies on smoking prevalence and smoking-attributable deaths in a middle income nation. PLoS Med. 2012;9(11):e1001336. https://doi. org/10.1371/journal.pmed.1001336

10. Brasil. Ministério da Saúde. Secretaria de Vigilância em Saúde. 
Departamento de Vigilância de Doenças e Agravos não Transmissíveis e Promoção de Saúde [homepage on the Internet]. Brasília: o Ministério [cited 2017 Jun 22]. Vigitel Brasil 2016: vigilância de fatores de risco e proteção para doenças crônicas por inquérito telefônico; 2017. [Adobe Acrobat document, 162p.]. Available from: http://portalarquivos.saude.gov.br/images/pdf/2017/ junho/07/vigitel_2016_jun17.pdf

11. Monteiro CA, Cavalcante TM, Moura EC, Claro RM, Szwarcwald CL. Population-based evidence of a strong decline in the prevalence of smokers in Brazil (1989-2003). Bull World Health Organ. 2007;85(7):527-34. https://doi.org/10.2471/BLT.06.039073

12. Brasil. Ministério da Saúde. Instituto Nacional de Câncer José Alencar Gomes da Silva (INCA) [homepage on the Internet]. Rio de Janeiro: INCA; [cited 2015 Oct 1]. Vigescola - Vigilância de tabagismo em escolares. Dados e fatos de 17 cidades brasileiras; 2006. Available from: http://www.inca.gov.br/vigescola/

13. Azevedo E Silva G, de Moura L, Curado MP, Gomes Fda S, Otero $U$, Rezende LF, et al. The Fraction of Cancer Attributable to Ways of Life, Infections, Occupation, and Environmental Agents in Brazil in 2020. PLoS One. 2016;11(2):e0148761. https://doi.org/10.1371/ journal.pone. 0148761

14. Secretaria de Estado da Saúde de São Paulo. Fundação Oncocentro de São Paulo [homepage on the Internet]. a Fundação [cited 2015 Oct 11. Acesso ao TABNET. Available from: http://fosp.saude.sp.gov. br/publicacoes/tabnet

15. National Cancer Institute. Surveillance, Epidemiology, and End Results Program (SEER) [homepage on the Internet]. Bethesda: National Cancer Institute; [cited 2015 Oct 1]. Câncer Stat Facts: Lung and Bronchus Cancer. Available from: http://seer.cancer.gov/ statfacts/html/lungb.htm

16. Cancer Research UK [homepage on the Internet]. London: Cancer Research UK; [cited 2015 Oct 1]. Lung Cancer Statistics. Available from: http://cancerresearchuk.org/health-professional/cancerstatistics/statistics-by-cancer-type/lung-cancer

17. dos Santos RS, Franceschini JP, Chate RC, Ghefter MC, Kay F, Trajano AL, et al. Do Current Lung Cancer Screening Guidelines Apply for Populations With High Prevalence of Granulomatous Disease? Results From the First Brazilian Lung Cancer Screening Trial (BRELT1). Ann Thorac Surg. 2016;101(2):481-6; discussion 4878. https://doi.org/10.1016/..athoracsur.2015.07.013

18. Ismael GF, Coradazzi AL, Neto FA, Abdalla KC, Milhomem PM, Oliveira JS, et al. Aspectos clínicos e histopatológicos em câncer de pulmão: análise dos dados de uma instituição no interior paulista entre 1997 e 2008. J Bras Oncol Clin. 2010;7(22):72-8.

19. Younes RN, Deutsch F, Badra C, Gross J, Haddad F, Deheinzelin D. Nonsmall cell lung cancer: evaluation of 737 consecutive patients in a single institution. Rev Hosp Clin Fac Med Sao Paulo. 2004:59(3):11927. https://doi.org/10.1590/S0041-87812004000300005

20. Westphal FL, Lima LC, Andrade EO, Lima Netto JC, Silva AS, Carvalho BC. Characteristics of patients with lung cancer in the city of Manaus, Brazil. J Bras Pneumol, 2009;35(2):157-63. https://doi. org/10.1590/S1806-37132009000200009

21. Barros JA, Valladares G, Faria AR, Fugita EM, Ruiz AP, Vianna $A G$, et al. Early diagnosis of lung cancer: the great challenge. Epidemiological variables, clinical variables, staging and treatment. J Bras Pneumol. 2006:32(3):221-7. https://doi.org/10.1590/S180637132006000300008

22. Novaes FT, Cataneo DC, Ruiz Junior RL, Defaveri J, Michelin OC, Cataneo AJ. Lung cancer: histology, staging, treatment and survival. J Bras Pneumol. 2008;34(8):595-600. https://doi.org/10.1590/S180637132008000800009

23. Araujo LH, Baldotto CS, Zukin M, Vieira FM, Victorino AP, Rocha $V R$, et al. Survival and prognostic factors in patients with nonsmall cell lung cancer treated in private health care. Rev Bras Epidemiol. 2014;17(4):1001-14. https://doi.org/10.1590/1809 4503201400040017

24. Mascarenhas E, Lessa G. Perfil clínico e sócio-demográfico de pacientes com câncer de pulmão não-pequenas células atendidos num serviço privado. J Bras Oncol Clin. 2010;7(22):49-54

25. Freitas ED. Aspectos epidemiológicos do câncer de pulmão em uma instituição privada. J Bras Oncol Clin. 2010;7:(22):55-9.

26. Caires-Lima R, Takahashi TK, Mak MP, Roiteberg FS, Teixeira CH, Mesquita CS, et al. Referral of lung cancer patients to specialized clinical oncology care: Instituto do Câncer do Estado de São Paulo 2010-2011. J Thorac Oncol. 2012;7(7):S111.

27. Lewis DR, Check DP, Caporaso NE, Travis WD, Devesa SS. US lung cancer trends by histologic type. Cancer. 2014;120(18):2883-92. https://doi.org/10.1002/cncr.28749

28. Costa G, Thuler LC, Ferreira CG. Epidemiological changes in the histological subtypes of 35,018 non-small-cell lung cancer cases in Brazil. Lung Cancer. 2016;97:66-72. https://doi.org/10.1016/j. lungcan.2016.04.019

29. de Souza MC, Vasconcelos AG, Rebelo MS, Rebelo PA, Cruz OG Profile of patients with lung cancer assisted at the National Cance Institute, according to their smoking status, from 2000 to 2007. Rev Bras Epidemiol. 2014;17(1):175-88. https://doi.org/10.1590/1415790X201400010014ENG

30. Ministério do Planejamento, Orçamento e Gestão. Instituto Brasileiro de Geografia e Estatística (IBGE) [homepage on the Internet]. Rio de Janeiro: IBGE [cited 2015 Oct 1]. Escassez e fatura: distribuição da oferta de equipamentos de diagnóstico por imagem no Brasil. Indicadores sociodemográficos e de saúde no Brasil, Rio de Janeiro; 2009. Available from: http://www.ibge.gov.br

31. Zamboni M, Monteiro AS. Bronchoscopy in Brazil. J Bras Pneumol. 2004;30(5):419-25 https://doi.org/10.1590/S180637132004000500004

32. Du Rand IA, Blaikley J, Booton R, Chaudhuri N, Gupta V, Khalid $\mathrm{S}$, et al. British Thoracic Society guideline for diagnostic flexible bronchoscopy in adults: accredited by NICE. Thorax. 2013; 68 Supp 1:i1-i44. https://doi.org/10.1136/thoraxjnl-2013-203618

33. Du Rand IA, Blaikley J, Booton R, Chaudhuri N, Gupta V, Khalid S, et al. Summary of the British Thoracic Society guideline for diagnostic flexible bronchoscopy in adults. Thorax. 2013:68(8):786-7. https:// doi.org/10.1136/thoraxjnl-2013-203629

34. Lannes D, Monteiro AS, Toscano E, Cavalcanti A, Nascimento M, de Biasi P, et al. Transbronchial needle aspiration of hilar and mediastinal lymph nodes [Article in Portuguese]. Rev Port Pneumol. 2007:13(5):651-8. https://doi.org/10.1016/S2173-5115(07)70360-3

35. Lima CD, Nunes RA, Saito EH, Higa C, Cardona ZJ, Santos DB. Results and complications of CT-guided transthoracic fine-needle aspiration biopsy of pulmonary lesions. J Bras Pneumol. 2011;37(2):209-16. https://doi.org/10.1590/S1806-37132011000200011

36. Tedde ML, Figueiredo VR, Terra RM, Minamoto $H$, Jatene FB. Endobronchial ultrasound-guided transbronchial needle aspiration in the diagnosis and staging of mediastinal lymphadenopathy: initial experience in Brazil. J Bras Pneumol. 2012;38(1):33-40. https://doi. org/10.1590/S1806-37132012000100006

37. Figueiredo VR, Jacomelli M, Rodrigues AJ, Canzian M, Cardoso PF, Jatene FB. Current status and clinical applicability of endobronchial ultrasound-guided transbronchial needle aspiration. J Bras Pneumol. 2013:39(2):226-37. https://doi.org/10.1590/S180637132013000200015

38. de Lima Lopes G Jr, Segel JE, Tan DS, Do YK, Mok T, Finkelstein EA. Cost-effectiveness of epidermal growth factor receptor mutation testing and first-line treatment with gefitinib for patients with advanced adenocarcinoma of the lung. Cancer. 2012;118(4):1032-9. https://doi.org/10.1002/cncr.26372

39. Ferreira CG. Lung cancer in developing countries: access to molecular testing. Am Soc Clin Oncol Educ Book. 2013:327-31 https://doi.org/10.1200/EdBook_AM.2013.33.327

40. Pontes LB, Bacchi CE, Queiroga EM, Piha T, Miranda PA, Freire $S$, et al. EGFR mutation screening in non-small cell lung cancer: results from an access program in Brazil. J Clin Oncol. 32:15 Suppl:1526.

41. Bacchi CE, Ciol H, Queiroga EM, Benine LC, Silva LH, Ojopi EB. Epidermal growth factor receptor and KRAS mutations in Brazilian lung cancer patients. Clinics (Sao Paulo). 2012;67(5):419-24. https:// doi.org/10.6061/clinics/2012(05)03

42. Melo AC, Inada HK Barros M, Terra SB, Ligorio C, Sugawara E, et al. Non-small cell lung cancer genotyping in a Brazilian cohort. Proceedings of the 14th World Conference on Lung Cancer; 2011 Jul 3-7: Amsterdam: The Netherlands. Aurora (USA): IASLC; 2011. P2.123.

43. Domingues PM, Montella T, Zukin M, Baldotto C, Ferreira C. Epidemiology and clinical outcomes of epidermal growth facto receptor (EGFR) mutant patients at the Brazilian National Cancer Institute (INCA). Proceedings of the 16th World Conference on Lung Cancer; 2015 Sep 6-9; Denver: USA. Aurora (USA): IASLC; 2015. P2.04-032.

44. De Sa VK, Nascimento EC, Meireles SI, Capelozzi VL. Epidermal growth factor receptor mutations in primary and metastatic adenocarcinomas from a tertiary hospital in São Paulo, Brazil. Proceedings of the 16th World Conference on Lung Cancer; 2015 Sep 6-9; Denver: USA. Aurora (USA): IASLC; 2015. P1.18-002. 
45. Yen C, Bitton RC, De Lima LGCA, Amadio AV, Takahashi TK, Marini $A M$, et al. Characterization of EGFR activating mutations in Brazilian patients with pulmonary adenocarcinoma. Proceedings of the 16th World Conference on Lung Cancer; 2015 Sep 6-9; Denver: USA Aurora (USA): IASLC; 2015. P2.04-041.

46. Saito A, Lima VCC, Dettino ALA, Macedo MP, Cunha IW, Dal Molin GZ, et al. Patterns of EGFR mutations in a cohort of 395 patients from a single institution in Brazil. Proceedings of the 16th World Conference on Lung Cancer; 2015 Sep 6-9; Denver: USA. Aurora (USA): IASLC; 2015. P2.04-033.

47. de Melo AC, Karen de Sá V, Sternberg C, Olivieri ER, Werneck da Cunha I, Fabro AT, et al. Mutational Profile and New IASLC/ATS/ERS Classification Provide Additional Prognostic Information about Lung Adenocarcinoma: A Study of 125 Patients from Brazil. Oncology. 2015;89(3):175-86. https://doi.org/10.1159/000376552

48. Gomes JR, Amarante MP, D'Alpino RD, Moreira RB, Souza TT, Lino $A R$, et al. Mutation profile in non-small cell lung cancer: analysis of a Brazilian population. J Clin Oncol. 2015; 33,15 Suppl:e19115.

49. Werutsky G, Debiasi M, Sampaio FHD, Nunes Filho PRS, Lopes Junior GDL. Global epidemiology of EGFR mutation in advanced nonsmall cell lung cancer. Proceedings of the 16th World Conference on Lung Cancer; 2015 Sep 6-9; Denver: USA. Aurora (USA): IASLC; 2015. P2.04-023.

50. Melo AC. Estudo epidemiológico de biomarcadores em câncer de pulmão não pequenas células [dissertation]. Rio de Janeiro: Instituto Nacional de Câncer; 2011.

51. Lopes LF, Bacchi CE. Anaplastic lymphoma kinase gene rearrangement in non-small-cell lung cancer in a Brazilian population. Clinics (Sao Paulo). 2012;67(7):845-7. https://doi.org/10.6061/ clinics/2012(07)23

52. Departamento de Informática do SUS - DATASUS [homepage on the Internet]. Brasília: Ministério da Saúde [cited 2015 Mar 15]. Assistência à Saúde. Available from: http://www2.datasus.gov.br/ DATASUS/index. php?area $=0202 \& i d=11633$

53. Conselho Regional de Medicina do Estado de São Paulo (CREMESP) [homepage on the Internet]. São Paulo: CREMESP; [cited 2016 Mar 1]. Demografia Médica no Brasil. Available from: http://cremesp.org. br

54. Tedde ML, Petrere O Jr, Pinto Filho DR, Pereira ST, Monteiro R Sassaki AM, et al. General thoracic surgery workforce: training, migration and practice profile in Brazil. Eur J Cardiothorac Surg. 2015 47(1):e19-24. https://doi.org/10.1093/ejcts/ezu411

55. Sánchez PG, Vendrame GS, Madke GR, Pilla ES, Camargo Jde J Andrade CF, et al. Lobectomy for treating bronchial carcinoma: analysis of comorbidities and their impact on postoperative morbidity and mortality. J Bras Pneumol. 2006;32(6):495-504. https://doi org/10.1590/S1806-37132006000600005

56. Stanzani F, Paisani Dde M, Oliveira Ad, Souza RC, Perfeito JA, Faresin SM. Morbidity, mortality, and categorization of the risk of perioperative complications in lung cancer patients. J Bras Pneumol. 2014;40(1):21-9. https://doi.org/10.1590/S180637132014000100004

57. Allen MS, Darling GE, Pechet TT, Mitchell JD, Herndon JE 2nd Landreneau RJ, et al. Morbidity and mortality of major pulmonary resections in patients with early-stage lung cancer: initial results of the randomized, prospective ACOSOG Z0030 trial. Ann Thorac Surg. 2006;81(3):1013-9; discussion 1019-20. https://doi.org/10.1016/j. athoracsur.2005.06.066

58. Brasil. Ministério da Ciência, Tecnologia, Inovações e Comunicações. Comissão Nacional de Energia Nuclear (CNEN) [homepage on the Internet]. Brasilia: CNEN; c2015 [cited 2015 Feb 15]. Instalações Autorizadas. Available from: http://cnen.gov.br /instalacoesautorizadas

59. Sociedade Brasileira de Radioterapia [homepage on the Internet]. São Paulo: a Sociedade [cited 2015 Feb 15]. Panorama da radioterapia no Brasil. Available from: http://sbradioterapia.com.br

60. Moraes FY, Marta GN, Hanna SA, Leite ET, Ferrigno R, da Silva JL, et al. Brazil's Challenges and Opportunities. Int J Radiat Oncol Biol Phys. 2015;92(4):707-12. https://doi.org/10.1016/j.jijobp.2014.12.063

61. Siqueira GS, Carvalho HA, Neves-Junior WF, Arruda FF, Correa SF Silva JL, et al. Atualização de Análise Institucional de Radioterapia Estereotáctica Extracraniana em Tumores de Pulmão não Pequenas
Células em Estádio Inicial em Pacientes Inoperáveis. Rev Bras Cancerol. 2011;57(4):570

62. Domingues PM, Zylberberg R, da Matta de Castro T, Baldotto CS, de Lima Araujo LH. Survival data in elderly patients with locally advanced non-small cell lung cancer. Med Oncol. 2013;30(1): 449. https://doi. org/10.1007/s12032-012-0449-8

63. Carvalho H, Saito NH, Gomes HC, Aquilar PB, Nadalin W Hypofractionated radiotherapy in advanced lung cancer. Radiol Bras. 1996;29(2):81-4.

64. Gabrielli FC, Abreu CE, Carvalho HA. Radioterapia torácica paliativa hipofracionada conformacional: experiência e resultados do Hospital Sírio-Libanês. Rev Bras Cancerol. 2011;57:566.

65. Sociedade Brasileira de Radioterapia. Braquiterapia no Brasil: análise do perfil dos centros de tratamento. São Paulo: a Sociedade; 2015.

66. de Aquino Gorayeb MM, Gregório MG, de Oliveira EQ, Aisen S, Carvalho Hde A. High-dose-rate brachytherapy in symptom palliation due to malignant endobronchial obstruction: a quantitative assessment. Brachytherapy. 2013;12(5):471-8. https://doi. org/10.1016/j.brachy.2012.10.007

67. Barrios P, Debiasi M, Lopes G, Barrios C. Impact of regulatory delays for cancer treatments in Brazil: An estimate of life-years lost due to the lack of approval of crizotinib for the treatment of ALK-positive lung cancer patients. Proceedings of the 16th World Conference on Lung Cancer; 2015 Sep 6-9; Denver: USA. Aurora (USA): IASLC 2015. ORAL27.07.

68. Younes RN, Pereira JR, Fares AL, Gross JL. Chemotherapy beyond first-line in stage IV metastatic non-small cell lung cancer. Rev Assoc Med Bras (1992). 2011;57(6):686-91. https://doi.org/10.1590/S010442302011000600017

69. Naime FF, Younes RN, Kersten BG, Anelli A, Beato CA, Andrade $\mathrm{RM}$, et al. Metastatic non-small cell lung cancer in Brazil: treatment heterogeneity in routine clinical practice. Clinics (Sao Paulo). 2007;62(4):397-404. https://doi.org/10.1590/S180759322007000400005

70. Zukin M, Barrios CH, Pereira JR, Ribeiro Rde A, Beato CA, do Nascimento $\mathrm{YN}$, et al. Randomized phase III trial of single-agent pemetrexed versus carboplatin and pemetrexed in patients with advanced non-small-cell lung cancer and Eastern Cooperative Oncology Group performance status of 2. J Clin Oncol. 2013;31(23):2849-53. https://doi.org/10.1200/JCO.2012.48.1911

71. Pereira JR, Martins SJ, Nikaedo SM, Ikari FK. Chemotherapy with cisplatin and vinorelbine for elderly patients with locally advanced or metastatic non-small-cell lung cancer (NSCLC). BMC Cancer. 2004;4:69. https://doi.org/10.1186/1471-2407-4-69

72. Caires-Lima $R$, et al. Erlotinib in metastatic pulmonary adenocarcinomas harbouring EGFR activating mutations in São Paulo--Brazil. Proceedings of the 15th World Conference on Lung Cancer; 2013 Oct 27-30; Sydney: Australia. Aurora (USA): IASLC 2015. P2.11-009

73. Freitas HC, Saito AO, Santos FN, Cunha IW, Dettino ALA, Macedo $M P$, et al. Treatment and clinical evolution of a cohort of 105 EGFR mutant patients from a single institution. Proceedings of the 16th World Conference on Lung Cancer; 2015 Sep 6-9; Denver: USA Aurora (USA): IASLC; 2015. P3.01-019.

74. Zylberberg R, Reinart T, Carbone DP, Araujo LH. Clinical outcomes and prognostic factors of patients with advanced non-small cell lung treated in clinical trials in Brazil: A single institution experience. J Clin Oncol. 2014;32 15 Suppl:e19144.

75. Leite GM, França MVS, Santana LM, Taveira MC, Zanardo G, Teles $L T$, et al. Descrição epidemiológica e clínica dos pacientes com câncer de pulmão tratados no Hospital Universitário de Brasília. Proceedings of the XVIII Congresso da Sociedade Brasileira de Oncologia Clínica. Brasília; 2013 Oct 23-26; São Paulo: Sociedade Brasileira de Oncologia Clínica. 606.

76. Pereira AA, Martins SJ, Lessa RC, Pinto FA, Gagliato DM, Santos ES et al. Comparison of bevacizumab versus pemetrexed in combination with platinum-based doublets in first-line treatment of advanced nonsmall cell lung cancer. J Clin Oncol, 2012. 30;15 Suppl:e18078.

77. Jardim DL, Gagliato Dde M, Ribeiro KB, Shimada AK, Katz A Bevacizumab as first-line therapy in advanced non-small-cell lung cancer: a Brazilian center experience. Drugs R D. 2012;12(4):207-16. https://doi.org/10.2165/11636760-000000000-00000 